\title{
Review of Temporary Employment Literature: Perspectives for Research and Development in Latin America
}

\author{
Revisión de la Literatura sobre Trabajo Temporal: \\ Perspectivas para la Investigación y el Desarrollo en \\ América Latina
}

\author{
Gabriel Martínez, Nele De Cuyper, and Hans De Witte \\ Katholieke Universiteit Leuven
}

\begin{abstract}
Temporary employment has become a major concern in the last decades: it is seen as the result of the continuous changes in the working system around the world. The effects of temporary employment for the employees and the organization have not been established yet, because there are many variables that can affect the observed outcomes. This article addresses the literature about temporary employment to date: an overview of the main characteristics associated with temporary employment and the most recent empirical studies concerning the outcomes associated with temporary employment is presented. Furthermore, attention is drawn to temporary work research in Latin America, in order to establish the development of the field and the perspectives for future research.
\end{abstract}

Keywords: temporary employment, outcomes, stepping stone, impression management.

El trabajo temporal se ha convertido en una preocupación mayor durante las pasadas décadas: se ve como el resultado de los continuos cambios en el sistema laboral alrededor del mundo. Los efectos del trabajo temporal para los trabajadores y las organizaciones no han sido establecidos aún, debido a que existen diversas variables que pueden afectar los resultados observados. El enfoque de este artículo es la literatura de trabajo temporal hasta la fecha, presentando una visión general de las principales características asociadas al trabajo temporal y los más recientes trabajos empíricos relativos a sus consecuencias. La atención se dirige a las investigaciones sobre trabajo temporal en América Latina, con el fin de establecer el desarrollo en el área y la perspectiva de investigaciones futuras.

Palabras clave: trabajo temporal, consecuencias, trampolín, control de impresiones.

\section{Introduction}

Considering the rapid development the world has suffered over the last 40 years, it is reasonable to think that all the processes related to the working context will also be affected by these changes. Elements such as the technologies used in the productive process, the specialization of the workforce and niches of development are just examples of the diversity of aspects that have been in constant change so far.

In the present document, the changes in the type of contract and how they relate to the workers' well-being, health, attitudes and intentional behaviour are reviewed, specifically focusing on the literature concerning how the type of contract influences

Gabriel Martínez, Research Group Work, Organizational and Personnel Psychology, Katholieke Universiteit Leuven, Belgium; Departamento de Psicología, Universidad de Chile, Santiago, Chile.

Nele De Cuyper, Research Group Work, Organizational and Personnel Psychology, Katholieke Universiteit Leuven, Belgium; Research Foundation Flanders (FWO-Vlaanderen), Brussels, Belgium.

Hans De Witte, Research Group Work, Organizational and Personnel Psychology, Katholieke Universiteit Leuven, Belgium.

Correspondence concerning this article should be addressed to Gabriel Martínez M., Research Group Center for Work, Organization and Personnel Psychology, Department of Psychology, K. U. Leuven, Tiensestraat 102, 3000, Leuven, Belgium. E-mail: gabriel.martinezmiranda@student.kuleuven.be 
the workers' responses. Several authors (see De Cuyper, De Jong, De Witte, Isaksson, Rigotti, \& Schalk, 2008) suggest that temporary employment may be a source of negative outcomes for both individuals and the organization. This issue has inspired many studies. However, it is argued that the analyses of these consequences have to take into account the specific conditions that surround the choice of working with a temporary contract. So far, most studies have been conducted in Europe and the United States; however, these provide an excellent background to introduce the subject in the Latin-American context.

This review starts with the definition and conceptualization of temporary employment. It then presents the psychological theories that have been used to explain the relationship between temporary employment and different outcomes. An overview of empirical findings is provided, specifically of those related to the organization, such as lack of commitment, low trust and reduced organization citizenship behaviours. Finally, studies conducted so far in this subject in Latin America are introduced in order to give a broad perspective compared to the studies conducted in the countries that belong to the Organisation for Economic Cooperation and Development (OECD).

\section{Definition}

As a result of the rapid advance of technologies, science and the constantly increasing competitiveness, companies have established policies of flexibility and adaptation to the economic changes in order to keep profits as high as they can (Kalleberg, 2000). Since employment situation around the world has become more competitive and unstable, companies and organizations have tended to offer more flexible employment conditions, focusing on potential problems (such as lower demand of the market) and the possibility of lay-offs (OECD, 2002). One of the actions taken to do this is to hire or fire workers according to the requirements of the market at that moment. The use of flexible contracts, such as in the form of temporary employment, is a way to achieve this. This allows organizations to avoid paying all compensations associated with firing permanent workers (Nollen \& Axel, 1996, cited in Gallagher \& McLean Parks, 2001).

To better understand this concept, it is important to describe first the main structure of organizations. According to the Dual Labour Market model (Constant \& Massey, 2005; Dickens \& Lang, 1985; Reich, Gordon, \& Edwards, 1973), organizations are composed of two main groups of workers: the core (or primary) group and the peripheral (or secondary) group. Core workers are mostly "standard" or permanent employees. These employees work under the socalled standard employment relationship (SER), which, according to certain authors (De Cuyper et al., 2008; Kalleberg, 2000), has some typical characteristics: it offers continuity of employment, which gives the workers a certain level of security regarding their working situation; the employees work in the employer's workplace and receive employer's supervision. In many countries workers also receive benefits and insurance.

The peripheral group are mostly "nonstandard" or temporary workers, and include temporary agency workers, shortterm, contingent and independent contractors (for further review, see Beard \& Edwards, 1995; Connelly \& Gallagher, 2004; De Witte \& Näswall, 2003; Kalleberg, 2000). All these types of employment are different from the standard employment in aspects such as working hours, terms of the contract, access to fringe benefits and supervision received. For example, some temporary workers are managed by agencies, giving the work relation a tripartite character (worker, agency and client organization). Most of the companies have a certain number of temporary workers as a way to deal with periods of decreased productivity or lower demand. This characteristic is considered by many authors as a quantitative (or numerical) external flexibility, concerning employees who belong to the "external" part of the company and not to the "core" (Dickens \& Lang, 1985; Valverde, Tregaskis, \& Brewster, 2000).

Although this dual structure may give a clearer idea of temporary employment, 
there is no real consensus about the concept. Polivka and Nardone (1989, p. 11) provided an exhaustive definition of contingent employment as "any job in which an individual does not have an explicit or implicit contract for long-term employment or one in which the minimum hours worked can vary in a non-systematic way". This definition is broader than the OECD's approach (2002), which suggests that temporary employment can be understood by both employer and employee when the end of the job is determined by an objective condition or situation, such as a certain date or the achievement of a goal. This latter definition includes persons who hold a seasonal contract, who are engaged in an employment agency or with a specific training contract. The OECD refers to temporary employment as a "dependent employment of limited duration" (2002, p. 170 ), which is used by many other authors to refer to the concept (see De Cuyper et al., 2008) and is the one setting the track for this document, focusing specifically on those workers that are employer-dependant and have previously determined when the work relationship ends.

Now that the concept and the idea of temporary employment have been clarified, it is necessary to examine the extension in which this type of contract is present within the workforce of analysis. In this case, the OECD countries will be used, due to the amount of studies and information regarding these subjects and because it is the region where most of the studies about temporary employment have been undertaken.

\section{Facts and Figures}

The number of temporary workers is not the same in all the OECD countries, showing a great variation from one country to another. For example, in the case of Spain one of every three contracts is temporary. Representing the other extreme are Luxemburg, Slovak Republic and the United States, where this rate is less than one in twenty (OECD, 2002). This gives us an initial idea concerning the nature of temporary employment as a phenomenon that can show high variation across countries.

\section{The Evolution of Temporary Employment}

Taking into consideration the data gathered between 1985 and 2002 (OECD, 2002), there is no clear tendency in the evolution and presence of temporary work among the OECD countries. In certain countries it is possible to observe an increasing tendency towards the use of temporary employment (France, Italy, the Netherlands, Portugal, and stronger in Spain), while in others a decrease in this kind of employment is observed (Greece and Luxemburg). These differences can be determined by several factors, such as protracted recessions, seasonal jobs (specifically in countries with high agricultural activity) or high level of employment protection (such as in France, Italy and Spain).

\section{The Trend within Temporary Employment}

Table 1 shows the trend in the use of different types of temporary employment. In most of the countries fixed-term contracts are the most popular; however, this trend is not followed by Mexico (seasonal contracts), the Netherlands (agency and on-call workers) and the United States (other types of temporary employment).

\section{Mobility}

The countries included in the OECD report (2002) present a high level of mobility, from temporary to permanent employment. Between $21 \%$ and $56 \%$ of temporary workers switched to permanent contracts within the first year, and after two years these rates increased to $34 \%$ and $71 \%$. This "increasing mobility" is more common in Denmark, the Netherlands, and the United Kingdom, while it is less common in Belgium, France, and Spain.

It is also important to consider that between $25 \%$ and $50 \%$ of temporary workers still are in a temporary employment position after two years and $25 \%$ of them are unemployed after two years (OECD, 2002). 
Table 1

Relative Distribution of Temporary Employment in the OECD Countries, by Component

\begin{tabular}{|c|c|c|c|c|c|c|}
\hline Country & Year & $\begin{array}{c}\text { Temporary } \\
\text { Help Agency } \\
\text { Workers }\end{array}$ & $\begin{array}{c}\text { Fixed-Term } \\
\text { Contracts }\end{array}$ & $\begin{array}{l}\text { On-Call } \\
\text { Workers }\end{array}$ & $\begin{array}{l}\text { Seasonal } \\
\text { Workers }\end{array}$ & $\begin{array}{c}\text { Other } \\
\text { Temporary } \\
\text { Workers }\end{array}$ \\
\hline Australia & 1997 & 21.7 & 75.9 & -- & 2.4 & -- \\
\hline Canada & 1995 & 2.1 & 50.4 & 33.0 & 14.5 & -- \\
\hline \multirow[t]{3}{*}{ France } & 1990 & 12.2 & 48.6 & -- & 2.8 & 36.4 \\
\hline & 1995 & 12.2 & 45.0 & -- & 3.1 & 39.7 \\
\hline & 2001 & 25.7 & 57.9 & -- & 3.4 & 40.9 \\
\hline Korea & 2001 & 5.7 & 63.9 & 13.4 & -- & 17.0 \\
\hline \multirow[t]{2}{*}{ Mexico } & 1995 & -- & 17.1 & -- & 47.8 & 35.1 \\
\hline & 2000 & -- & 9.3 & -- & 54.0 & 36.6 \\
\hline \multirow[t]{3}{*}{ Netherlands } & 1992 & 25.1 & 28.1 & 29.6 & -- & 17.3 \\
\hline & 1995 & 31.4 & 27.7 & 28.7 & -- & 12.2 \\
\hline & 1999 & 36.8 & 23.8 & 27.3 & -- & 12.1 \\
\hline \multirow[t]{3}{*}{ United Kingdom } & 1992 & 6.7 & 48.1 & -- & 6.5 & 38.7 \\
\hline & 1995 & 10.4 & 54.0 & -- & 4.4 & -- \\
\hline & 2000 & 15.8 & 48.3 & -- & 4.1 & 31.8 \\
\hline \multirow[t]{2}{*}{ United States } & 1995 & 14.1 & -- & 14.2 & -- & 71.8 \\
\hline & 2000 & 13.2 & -- & 14.8 & -- & 72.0 \\
\hline
\end{tabular}

Source: OECD (2002).

-- information not gathered.

\section{The Temporary Worker}

According to the data from the sample, younger people (between ages 15 to 24) have three times more chances of having a temporary contract compared to older workers. Also, those workers who did not complete their secondary education are 60\% more likely to have a temporary contract, compared to those more educated. Regarding gender differences, in some countries (Belgium, Finland, Japan, and the Netherlands) the presence of women in temporary employment is significantly higher compared to men.

According to the sample from the OECD report (2002), temporary workers perform mostly in service areas, except in the case of Mexico, where most of the temporary workers are in the agricultural sector.

\section{Theoretical Framework}

The previously presented data suggests that temporary employment is a growing phenomenon in almost every economy around the globe, becoming an interesting subject to study in order to prevent potential negative effects for both employees and organizations.

According to De Cuyper et al. (2008), there is no available theoretical framework to analyse the effects of temporary employment. Nevertheless, general psychological theories may offer a good starting point for the analyses, although these have mostly been developed against the backdrop of the permanent employment relationship. They can be organized in two main groups: work stress models, and social comparison and social exchange theories.

Work stress models try to explain the consequences of temporary employment by underlining certain characteristics that make temporary workers more prone to suffer work related strain (see De Cuyper et al., 2008). There are three relevant variables. First, temporary workers are peripheral to the organization, meaning that they are not the main concern of the employers regarding certain aspects such as benefits, wages, promotion or further training. This 
idea is advanced in theories such as the Flexible Firm model (Atkinson, 1984, cited in Valverde et al., 2000) and the Dual Labour Market model (Doeringer \& Piore, 1971, cited in Dickens \& Lang, 1985). The resulting adverse working conditions for the temporary employees can cause, as a consequence, a decrease in the worker's well-being and deteriorate performance at the workplace (Rousseau \& Libuser, 1997). The second variable to consider is the reduced level of control that temporary workers have over their job. Temporary workers are usually hired to perform a very specific task that has been previously defined by the employer. Therefore, temporary workers have few possibilities for deciding how to do their work, to use specific skills or to make any other kind of decisions within the workplace (De Witte \& Näswall, 2003). In addition, since temporary workers are new members of the organization, they have to assimilate procedures and aspects of the organization, becoming another potential source of stress (see De Cuyper et al., 2008). The lack of support from co-workers, supervisors or even the union (De Witte \& Näswall, 2003) can also be a source of stress and detrimental to well-being. The third determinant has to do with the lack of control that temporary workers might experience regarding the demands of the employer (or employers). The employee is under great pressure to perform in a good way and also has to look for alternative sources of income, foreseeing the future unemployment. All these are highly stressful situations, considering the level of uncertainty the employee might experience regarding the future of the working conditions and the job itself.

As a result of the suffered stress, workers can go through a physical and mental weakening, therefore increasing the likelihood of presenting sickness related absenteeism. Other consequences, such as deteriorated family and organizational relations, can be observed and might also affect the workers' productivity.

The second type of theories used to understand the relationship between contract type and the negative outcomes among workers are social comparison and social exchange theories. These theories rely on the notion that workers evaluate their situation in terms of perceived fairness in the workplace (see Buunk \& Gibbons, 2007). If the temporary workers feel they are not receiving what they think they deserve, this might generate a sense of deprivation and, therefore, create a negative perception of the working situation (Turnley \& Feldman, 1999).

One approach to this is the concept of the psychological contract. According to Rousseau, the psychological contract concerns "the individual beliefs in a reciprocal obligation between individual and the organization" (1989, p. 121). The author argues that the formal contract defines the framework and zone of negotiability of the psychological contract, becoming the set of expectations employees have regarding their obligations and entitlements. As observed in Rousseau's research (1990), the psychological contract establishes the most basic elements that can be considered and expected from the relationship and, therefore, sets the framework within which both the employer and the employee will interact. Rousseau also proposes the existence of two different types of psychological contract: transactional and relational. The transactional is more focused on the economic exchange between the employer and the employee, is for a specified period of time and with a narrow scope and definition; the relational psychological contract is based on a non-economic/affective exchange, with no defined duration and a broad scope and definition. Temporary employees, who are usually required for a specific task, for a specific amount of time and have the required skills, are more likely to hold a transactional contract (Millward \& Hopkins, 1998). In contrast, permanent workers, which are supposed to have a long term relationship with the employer and a stronger commitment with the organization, are more likely to hold a relational contract.

According to Rousseau (1995, cited in Millward \& Hopkins, 1998), aspects such as trust, attachment, and commitment are left out of transactional contracts. The relationship is oriented towards the exchange of money for performing certain tasks, with- 
out any other kind of motivation for the employee. It is expected that the employee will demonstrate a serious lack of identification with the organization's values and goals.

The relationship between the employee and the organization is also reviewed by the Theory of Work Adjustment [TWA] (Dawis, 2004; Dawis, Lofquist, \& Weiss, 1968), which places emphasis on the interaction and how the workers change to fit into the workplace. This theory highlights the congruence between the requirements of the organization and the requirements of the employee. First, it is important to consider the employee's needs and expectations, which are supposed to be fulfilled through the organization (Dawis, 2004). Second, the employee has skills that are useful to succeed in this fulfilment. Third, most interactions between the employee and the organization are oriented towards these requirements. However, not only the employee has needs but the organization as well. The employees must have the right skills according to the organization's requirements and the organization must reinforce the employees by giving them what they expect.

According to this, when there is a certain level of discrepancy between the needs of the employee and the reinforcement given by the organization, there will be a change in the employee's behaviour in order to reduce the dissonance. And just as it is pointed out by Thorsteinson (2003), this degree of dissonance will lead to employee dissatisfaction. Regarding this, there are two ways to reduce the conflict: changing the employee's needs or the organization's conditions. If both strategies are unsuccessful, the employee will eventually quit (Dawis, 2004; Dawis et al., 1968). In line with the TWA, the bad perception of the employee regarding his or her relation with the employer does not start from the working conditions per se; it rather comes from unfulfilled expectations. If the worker wants a temporary job and gets a permanent job, the outcomes might be as pernicious as if the worker gets a temporary job expecting a permanent one.
Outcomes and Temporary Employment

As it was previously reviewed, temporary employment can be associated with different kinds of outcomes, both for the employee and the organization. Although most of the studies addressing this subject are focused on the unfavourable outcomes, the findings in this field have not always been consistent and there are examples of different types of consequences associated with temporary employment.

\section{Employee's Well-Being}

The negative consequences temporary employment can have over the worker's health and well-being have been addressed in several studies. Virtanen, Kivimäki, Joensuu, Virtanen, Elovainio, and Vahtera (2005) found a direct association between temporary employment and psychological morbidity, as well as a higher risk of occupational injuries. The authors related the presence of this risk to the fact that employers usually do not take enough time to provide training and proper supervision for the temporary employees. Job satisfaction has also been found to be inversely related to temporary employment by several researchers (Bardasi \& Francesconi, 2004; Booth, Francesconi, \& Frank, 2002).

Although several of the studies show an inverse association between temporary employment and well-being, there are studies that show that this is not a constant phenomenon. For example, De Cuyper and De Witte (2006) found no significant differences between temporary and permanent workers regarding job and life satisfaction. These results are similar to those obtained by De Witte and Näswall (2003) and by Thorsteinson (2003), this last one comparing part-time and full-time employees. Bernhard-Oettel, Sverke, and De Witte (2005) also established that the type of contract does not have a significant influence on mental distress.

Some studies have also found an indirect association between temporary employ- 
ment and worker's well-being. For example, Virtanen et al. (2005) found that temporary employment was inversely associated to sickness related absence when compared to permanent employment, which was consistent with the findings made by Bardasi and Francesconi (2000).

\section{Organizational Outcomes}

There are different relevant variables to evaluate once examining the association between temporary employment and organizational outcomes. Commitment and organizational citizenship behaviours (OCB) are the most important for providing further information about the workers' attitudes towards their working situation, although studies done so far have addressed other outcomes as well.

Regarding the unfavourable consequences that can be associated with temporary employment, Bardasi and Francesconi (2000) found that the inexperience of temporary employees, added to the lack of induction and investment in their skills, might have a negative influence over the attitudes they have concerning security and the best way to perform their duties. Regarding commitment, Felfe, Schmook, Schyns, and Six (2008) noticed that temporary employees who chose this type of contract show less commitment compared to those who did not. Millward and Hopkins (1998) also noticed that it is more likely to find a higher level of commitment among workers with a relational psychological contract (permanent workers) compared to those with a transactional psychological contract (temporary employees), as well as McInnis, Meyer, and Feldman (2009) did. Kalleberg and Rognes (2000) observed that lack of trust, perceived unfairness, and lower affective attachment can also be related to transactional contracts. These results are similar to those found by McDonald and Makin (2000) when comparing permanent and non-permanent staff.

However, not every study has found negative consequences associated with temporary employment. Regarding job commitment, Martin and Hafer (1995) and De Witte and Näswall (2003) found no significant difference between temporary and permanent employees. The last authors found similar results about job satisfaction.

Engellandt and Riphahn (2005) observed even a higher level of employee effort in temporary workers compared to permanent ones. These authors argue that temporary workers are more likely to work harder, although this performance level is more commonly found among employees that have a possibility of going upwards in the organization. Feldman (2005) found similar results, pointing out that contingent workers with expectations of future permanent employment are more likely to perform at higher levels and show more OCB compared to those who do not have these expectations. As pointed out by the author, the contingent employees respond to three characteristics: they have no permanent relationship with an employer, they work less than 35 hours with any employer and the contract is of limited duration. This approach is more used in the United States, while the definition of temporary employment given by the OECD is more popular among European countries. Although the present document is almost completely focused on the temporary employment definition, it is good to have a wider point of view of the research done in other contexts.

\section{Explanations for the Inconsistent Pattern of Results}

The heterogeneity of these results makes it difficult to establish the definitive nature of temporary employment and its effects over the workers. There is no doubt that it has an influence over employees, but this influence does not always follow the same pattern. According to several authors (Carroll, 1999; Gallagher \& McLean Parks, 2001; Larsson, Lindqvist, \& Norsdström Skans, 2005; Zijl, van den Berg, \& Heyma, $2004)$, it is very important to examine the motivation that drives employees to choose 
a temporary contract over a permanent one. Not all individuals are compelled to take a temporary position because there is a lack of better options, but for a very important part of this group temporary employment is taken considering certain characteristics that are attractive for the future employees. Working part-time, just for a season or on a call-in basis, is often perceived as a valuable condition for some individuals. Some of the explanations given for this behaviour are: the possibility of having access to different experiences and working skills that can improve their human capital, a seasonal job can be a source of extra-income, and temporary employment can be the best way to obtain permanent employment in the future (Zijl et al., 2004).

The stepping stone hypothesis. One concept that can help to explain these previously presented inconsistent findings is the stepping stone hypothesis. It basically refers to the functionality that temporary employment has for unemployed people towards obtaining a permanent job. In this case, temporary employment would work as a first step into the permanent working market (Gallagher \& McLean Parks, 2001; Larsson et al., 2005; Zijl et al., 2004). This is an interesting point to consider, since the unemployed group does not see temporary jobs just as a way to get out of unemployment [concept of "dead-end"] (see Larsson et al., 2005), or bad or against their needs. Negative outcomes that are usually associated with temporary employment are not observed in these cases. Just as it was pointed out by Engellandt and Riphahn (2005), Feldman (2005), and De Jong and Schalk (2005, cited in De Cuyper et al., 2008), more employee effort is observed among temporary workers who are willing to obtain a permanent job in the company where they are working. This change in the employees' attitudes towards the organization can also affect aspects such as showing higher OCB, more organizational commitment, less absenteeism or less turn-over intentions (Goudswaard, Kraa, \& Dhondt, 2000, cited in De Cuyper et al., 2008; Klein Hesselink, Koppens, \& Van Vuuren, 1998, cited in De Cuyper et al., 2008; Rousseau, 1989).
Rousseau (1990) noticed that temporary employees seeking a long-term relationship with their organizations, even when maintaining a transactional psychological contract, showed a more "relational" interaction with their employers, resulting in more commitment to the organization and OCB.

The stepping stone hypothesis provides an explanation for some of the results found in studies concerning commitment and other outcomes related to temporary employment. Variables that are usually associated with having a lower presence in temporary employment (commitment, OCB, job effort) are now observed in higher levels compared to permanent workers. These "contradictory" results are supported by the idea of temporary employment as a stepping stone into a more permanent and stable job situation. Because the workers consider their present employment situation to be temporary, and in order to make themselves attractive to the employer, they will try to enhance their performance: showing more OCB, a greater commitment to the organization, and less absenteeism.

Impression management. The process of controlling the image others may have about us is called impression management (see Bolino \& Turnley, 2003; Leary \& Kowalski, 1990). This process can be used in the working context by employees who use different tactics to make their employers think about them as valuables elements for the organization. According to Jones and Pittman (1982, cited in Bolino \& Turnley, 2003) these tactics can be: ingratiation, where the individual flatters and does favours for others; self-promotion, where the workers try to be viewed as competent touting their abilities; exemplification, whereby the workers try to be seen as dedicated through performing beyond their regular duties; supplication, where the individuals want be to be seen as needy by showing their weaknesses; and intimidation, where the workers try to be seen as intimidating by bullying others. Due to the characteristics of temporary employment and its potential outcomes, self-promotion and exemplification are more likely to be the tactics chosen by temporary employees to show their value to the organization, in order to be considered for 
a permanent position. Since temporary employees hold a contract that leads inevitably to an end, those who are willing to stay in the organization for longer periods (let us say, with a permanent contract) are more likely to engage in impression management techniques to achieve this goal. This is what Leary and Kowalski (1990) called impression motivation and refers to the variables that motivate individuals to use impression management behaviours to achieve desired outcomes. The presence of impression management behaviour in temporary employees is directly associated with their intentions of staying in the organization or to achieve a better position. Sias, Kramer and Jenkins (1997) showed that temporary employees who do not think nor expect to stay in the organization for much longer have little concern regarding impression management behaviours.

\section{Latin American and Temporary Employment}

So far, the presented data have come from studies conducted in Europe. The question now is: what is the present situation of temporary employment in Latin America? Before doing any review of this subject, it is important to look at the similarities in the concept between Europe and Latin America in order to establish a "base line" for the analysis. In Latin American literature, the figure of temporary employment does not exist as it does in the European case. An early definition of this kind of employment was given by Galin (1986) and refers to any form of employment that differs from the typical work arrangement characteristics: working full time, having only one employer and being protected by legislation or any kind of group negotiation. According to this author, any working contract that does not meet any of these characteristics is called "atypical" or "precarious", just like clandestine jobs, sub-hiring, short-term work and temporary help agencies. It is interesting to observe that in both cases the types of contracts considered are almost the same, but the emphasis is different: the first definition is focused on the temporary aspect, while the second is oriented towards characteristics, such as the number of employers and the protection of the worker.

How extended is this kind of employment in Latin America? According to the International Labour Organization ([OIT in Spanish], 2004), Latin American economies show high rotation within the workforce, indicating a low level of permanence in the same job (see Table 2) and giving us little

Table 2

Job Permanence in Countries from the OECD and Latin America

\begin{tabular}{lccc}
\hline Country & Average Job & $\begin{array}{c}\text { Percentage of } \\
\text { Workers with } \\
\text { Permanence }<1 \\
\text { Year }\end{array}$ & $\begin{array}{c}\text { Percentage of } \\
\text { Workers with } \\
\text { Permanence }>10 \\
\text { Years }\end{array}$ \\
\hline Greece & Permanence & 9.8 & 52.1 \\
Japan & 13.6 & 8.3 & 43.2 \\
Italy & 12.2 & 10.8 & 49.3 \\
France & 12.2 & 15.3 & 44.2 \\
10 Countries Member of the European Union & 11.2 & 14.8 & 41.5 \\
Germany & 10.6 & 14.3 & 41.7 \\
Denmark & 10.6 & 20.9 & 31.5 \\
United Kingdom & 8.3 & 19.1 & 31.2 \\
Argentina & 8.2 & 27.5 & 21.2 \\
United States & 6.7 & 24.5 & 26.2 \\
Perú & 6.6 & 29.0 & 20.1 \\
Chile & 6.3 & 34.5 & 18.8 \\
Brazil & 5.5 & 37.2 & 16.4 \\
\hline
\end{tabular}


idea regarding the nature of the jobs. In the data presented, the Latin American country with the highest average of years of job permanence (Argentina: 6.7) is half of the highest country in Europe (Greece: 13.3). As pointed out by Salazar and Rivas (2004), Beccaria (1997, cited in Lindenboim, 2001), and previously by Galin (1986), in Latin America there is an increasing tendency towards flexibility of employment conditions and the use of atypical contracts. The reasons that lead Latin American employers to use atypical contracts are the same as those in Europe: reducing costs, increasing flexibility and avoiding legal obligations (Lindenboim, 2001; Salazar \& Rivas, 2004; Tókman, 2007; Zelaschi, 2007, April). In the case of most Latin American economies, flexibility of working conditions (such as a lower regularization of contracts) was used in order to generate more jobs (Ernst, Berg, \& Auer, 2007; Useche \& Castellano, 2002), specially among women, young people and those without a regular working situation. Temporary employment was supposed to be just a transitional type of work, focused on the promotion of new jobs in a more demanding and constantly changing economic environment. However, instead of being a transitional type of work it became the norm, resulting in a decrease of permanent positions (Zelaschi, 2007, April). Useche and Castellano (2002) refer to this situation as a "precarization" of the working situation in Latin America, leading to conditions that might result in negative consequences for the employees. It is important to take into consideration that these changes in economic policies took place in countries with bigger and more complex working contexts, such as Brazil, Mexico or Argentina, but it also happened in smaller countries, like Chile or Venezuela.

As an example, in Chile there is an observed tendency to use more atypical contracts. As a consequence of this, participation of temporary employees in the different industries has increased in the last years (see Aguiar, 2007): temporary agency workers increased from $6.4 \%$ of the workforce in 1999 to $7.3 \%$ in 2004 . In 2003 temporary workers were $12 \%$ of the total workforce and in 2000 part-time workers were $10 \%$.
Aguiar points out several causes of the origin of this tendency: changes in the productive structure, the globalization of the economy, the new demands of the market, and the increase of competitiveness of organizations. Useche and Castellano (2002) consider that all these factors have influenced the emergence of atypical contracts and their increasing use over the years all over Latin America.

However, and considering Chile as an example, temporary employment might not be homogeneously present in the different working sectors. According to the Chilean Labour Survey ([Encuesta Laboral] Chile, Dirección del Trabajo, 2006), the highest presence of temporary contracts can be observed in the construction industry $(72.6 \%)$ and in farming $(40.6 \%)$, where work is determined by the season or the duration of the project. Therefore, not only national or international policy factors have to be taken into account but also the organization and structure of the economic sector itself.

The observed trends can provide a slight idea of the actual situation of temporary work in Latin America. However, there is little research regarding the effects of temporary employment on the workers' wellbeing and the organization, and most of it is focused towards "informal contracts", which is another category used in Latin America (see Galin, 1986; Zelaschi, 2007, April).

\section{Discussion}

As it has been reviewed in this article, temporary (or non-standard) employment since its beginning has become an increasingly strong element in the working context. As we have noticed in most of the OECD countries, temporary employment is part of the regular organization of the workplace, even though permanent employment is still the preferred form of contract. Although temporary employment has become more common in most of the countries, in other countries temporary employment has showed a decrease. This is very important to consider due to the fact that temporary employment has increased as a result of more flexible working policies. Nevertheless, it is not an inherent element of the working 
situation. Organizations and industries can keep their competitiveness and presence in their niches by market policies from the government that give enough support and warranties for their earnings without turning all their pay-rolls into temporary contracts. The tendency observed in the OECD countries is similar to that observed in Latin America, so it is possible to think that the global working situation has affected most of the countries in a very similar way. The question is: what makes the difference between one country and another? Why do some countries show increasing levels of temporary employment while others are reducing this indicator? Considering the situation of Spain and its flexible employment regulation (see Dolado, García-Serrano, \& Jimeno, 2002; Güell \& Petrongolo, 2007), temporary employment may only be the natural result of economic policies that are more concerned with flexibility and companies' earnings than employees' well-being.

However, temporary employment does not necessary mean bad working conditions or negative outcomes for the employees. Several studies (De Witte \& Näswall, 2003; Engellandt \& Riphahn, 2005; Feldman, 2005; Martin \& Hafer, 1995; Thorsteinson, 2003) have shown that temporary employment can actually result in better outcomes compared to permanent employment. Variables such as commitment and OCB are observed in higher levels in temporary workers, providing a hint on their perception of their working situation. This aspect is related to choices made by the employees and how their occupation fits their needs and desires. Therefore, the job is not measured by the value it has by itself; it is necessary to consider other variables before evaluating the working context and the effects it has over the workforce. In the case of the OECD countries this effort has already begun to show results (OECD, 2002), presenting studies that clarify the characteristics of temporary employment and its consequences. In Latin America there is a lack of studies concerning this phenomenon and the consequences it has. All the studies conducted in the field are descriptive and refer to the prevalence of the phenomenon in different countries. Although this data can give an idea about the evolution of this type of employment, it is hard to get further insight without research on the more "relational" aspects of it.

Another element that is worthy of further study is the concept of stepping stone and the role it plays in workers' perception regarding their job situation (Gallagher \& McLean Parks, 2001; Larsson et al., 2005; Zijl et al., 2004). It is important to keep in mind the personal appreciation of the employment contract instead of just the inherent characteristics of it. In the case of temporary employment, this difference is basic to consider if such a situation is or is not pernicious for the workforce. When employees consider temporary employment, at the moment they consider it to be valuable, regardless of the usually "negative" aspects related to it; the whole working experience can be lived as a previous and needed step to something better beyond that and not just as a "dead-end". The stepping stone idea is relevant in order to change the perspective regarding temporary employment and how it can be considered by the organization and the employees themselves.

Another aspect that goes against the development of research in Latin America that should be improved is the absence of a consensus regarding the concept. Temporary employment as it is conceptualized by the OECD (2002) is different from that used in Latin America, where "atypical employment" is used to refer to all contracts that are not permanent. However, these "atypical" contracts are almost the same as the temporary contracts in the OECD countries, so the investigations done so far can be used as references for Latin American researchers. The lack of a stronger research basis makes the development of this area more difficult and slower; even though some efforts have been made in different countries in order to answer some of the questions regarding this subject (see Zelaschi, 2007, April). Further research has to be incentivized in order to address the different aspects that characterize temporary employment: its causes, its related outcomes and the variables that can affect them. This is due to the fact that temporary employment and the consequences that this type of contract might have on the employees can affect not 
only the individuals but the organization as well (see De Cuyper et al., 2008).

\section{References}

Aguiar, S. (2007). Observaciones sobre las transformaciones del trabajo. Tendencias a la precarización $y$ categorías teóricas (Cuaderno $\mathrm{N}^{\mathrm{o}} 1$ ). Santiago, Chile: Estudios del Trabajo. Retrieved April 16, 2009, from http://www.estudiosdeltrabajo.cl/wpcontent/uploads/2009/03/11.doc

Bardasi, E. \& Francesconi, M. (2000). The effect of nonstandard employment on mental health in Britain. Essex, England: University of Essex, Institute of Social and Economic Research.

Bardasi, E. \& Francesconi, M. (2004). The impact of atypical employment on individual wellbeing: Evidence from a panel of British workers. Social Science and Medicine, 58, 1671-1688.

Beard, K. M. \& Edwards, J. R. (1995). Employees at risk: Contingent work and the psychological experience of contingent workers. In C. L. Cooper \& D. M. Rousseau (Eds.), Trends in organizational behavior (Vol. 2, pp. 109-126). New York: John Wiley.

Bernhard-Oettel, C., Sverke, M., \& De Witte, H. (2005). Comparing three alternative types of employment with permanent full-time work: How do employment contract and perceived job conditions relate to health complaints? Work \& Stress, 19, 301-318.

Bolino, M. C. \& Turnley, W. H. (2003). More than one way to make an impression: Exploring profiles of impression management. Journal of Management, 29, $141-160$.

Booth, A. L., Francesconi, M., \& Frank, J. (2002). Temporary jobs: Stepping stones or dead ends? The Economic Journal, 112(480), F189-F213.

Buunk, A. P. \& Gibbons, F. X. (2007). Social comparison: The end of a theory and the emergence of a field. Organizational Behavior and Human Decision Processes, 102, 3-21.

Carroll, N. (1999). Non-standard employment: A note on levels, trends, and some implications. Labour Market Bulletin, 101-121. Auckland, New Zealand: Department of Labour.

Chile, Dirección del Trabajo (2006). Encuesta Laboral (ENCLA). Santiago, Chile: Author.

Connelly, C. E. \& Gallagher, D. G., (2004). Emerging trends in contingent work research. Journal of Management, 30, 959-983.

Constant, A. \& Massey, D. S. (2005). Labor market segmentation and the earnings of German guestworkers. Population Research and Policy Review, 24, 489-512.

Dawis, R. V. (2004). The Minnesota theory of work adjustment. In S. D. Brown \& R. W. Lent (Eds.), Career development: Putting theory and research into practice (pp. 3-23). Hoboken, NJ: John Wiley.

Dawis, R. V., Lofquist, L. H., \& Weiss, D. J. (1968). A theory of work adjustment (a revision). Minnesota studies in vocational rehabilitation. Minneapolis, MN: University of Minnesota Press.
De Cuyper, N., De Jong, J., De Witte, H., Isaksson, K., Rigotti, T., \& Schalk, R. (2008). Literature review of theory and research on the psychological impact of temporary employment: Towards a conceptual model. International Journal of Management Reviews, 10, 25-51.

De Cuyper, N. \& De Witte, H. (2006). The impact of job insecurity and contract type on attitudes, wellbeing and behavioural reports: A psychological contract perspective. Journal of Occupational and Organizational Psychology, 79, 395-409.

De Witte, H. \& Näswall, K. (2003). 'Objective' vs 'subjective' job insecurity: Consequences of temporary work for job satisfaction and organizational commitment in four European countries. Economic and Industrial Democracy, 24, 149-188.

Dickens, W. \& Lang, K. (1985). A test of dual labor market theory. The American Economic Review, $75,792-805$.

Dolado, J. J., García-Serrano, C., \& Jimeno, J. F. (2002). Drawing lessons from the boom of temporary jobs in Spain. The Economic Journal, 12(480), F270F295.

Engellandt, A. \& Riphahn, R. T. (2005). Temporary contracts and employee effort. Labour Economics, 12, 281-299.

Enrst, C., Berg, J., \& Auer, P. (2007). Retos en materia de empleo y respuestas de política en Argentina, Brasil y México. Revista de la CEPAL, 91, 95110.

Feldman, D. C. (2005). Toward a new taxonomy for understanding the nature and consequences of contingent employment. Career Development International, 11, 28-47.

Felfe, J., Schmook, R., Schyns, B., \& Six, B. (2008). Does the form of employment make a difference? Commitment of traditional, temporary, and self-employed workers. Journal of Vocational Behavior, 72, 81-94.

Galin, P. (1986). Asalariados, precarización y condiciones de trabajo. Nueva Sociedad, 85, 30-38.

Gallagher, D. G. \& McLean Parks, J. (2001). I pledge thee my troth... contingently. Commitment and the contingent work relationship. Human Resource Management Review, 11, 181-208.

Güell, M. \& Petrongolo, B. (2007). How binding are legal limits? Transitions from temporary to permanent work in Spain. Labour Economics, 14, 153-183.

Kalleberg, A. L. (2000). Nonstandard employment relations: Part-time, temporary and contract work. Annual Review of Sociology, 26, 341-365.

Kalleberg, A. L. \& Rognes, J. (2000). Employment relations in Norway: Some dimensions and correlates. Journal of Organizational Behavior, $21,315-335$.

Larsson, L., Lindqvist, L., \& Nordström Skans, O. (2005). Stepping-stones or dead-ends? An analysis of Swedish replacement contracts (Working Paper 2005:18). Uppsala, Sweden: IFAU-Institute for Labor Market Policy Evaluation.

Leary, M. R. \& Kowalski, R. M. (1990). Impression management: A literature review and twocomponent model. Psychological Bulletin, 107, 34-47. 
Lindenboim, J. (2001). Transformaciones del mercado de trabajo en los noventa: empleo, desempleo $y$ desprotección laboral. Unpublished manuscript, Centro de Estudios sobre Población, Empleo y Desarrollo, Universidad de Buenos Aires, Argentina.

Martin, T. N. \& Hafer, J. C. (1995). The multiplicative interaction effects of job involvement and organizational commitment on the turnover intentions of full- and part-time employees. Journal of Vocational Behavior, 46, 310-331.

McDonald, D. J. \& Makin, P. J. (2000). The psychological contract, organisational commitment and job satisfaction of temporary staff. Leadership \& Organization Development Journal, 21, 84-91.

McInnis, K. J., Meyer, J. P., \& Feldman, S. (2009). Psychological contracts and their implications for commitment: A feature-based approach. Journal of Vocational Behavior, 74, 165-180.

Millward, L. J. \& Hopkins, L. J. (1998) Psychological contracts, organizational and job commitment. Journal of Applied Social Psychology, 28, 15301556.

Organisation for Economic Co-operation and Development (2002). Employment outlook. Paris: Author.

Organización Internacional del Trabajo (2004). Panorama laboral. Lima: Author.

Polivka, A. E. \& Nardone, T. (1989). On the definition of "contingent work". Monthly Labor Review, 112(12), 9-14.

Reich, M., Gordon, D., \& Edwards, R. (1973). A theory of labor market segmentation. The American Economic Review, 63, 359-365.

Rousseau, D. M. (1989). Psychological and implied contracts in organizations. Employee Responsibilities and Rights Journal, 2, 121-139.

Rousseau, D. M. (1990). New hire perceptions of their own and their employer's obligations: A study of psychological contracts. Journal of Organizational Behavior, 11, 389-400.

Rousseau, D. M. \& Libuser, C. (1997). Contingent workers in high risk environments. California Management Review, 39(2), 103-123.
Salazar, N. \& Rivas, F. E. (2004). La precariedad laboral y su incidencia en las políticas sociales de la V república: una mirada especial a las misiones. Visión Gerencial, 3(1), 62-77.

Sias, P. M., Kramer, M. W., \& Jenkins, E. (1997). A comparison of the communication behaviors of temporary employees and new hires. Communication Research, 24, 731-754.

Thorsteinson, T. J. (2003). Job attitudes of part-time vs. full-time workers: A meta-analytic review. Journal of Occupational and Organizational Psychology, 76, 151-177.

Tókman, V. E. (2007). Informalidad, inseguridad y cohesión social en América Latina. Santiago, Chile: Naciones Unidas, CEPAL, División de Desarrollo Social.

Turnley, W. H. \& Feldman, D. C. (1999). A discrepancy model of psychological contract violations. Human Resources Management Review, 9, 367-386.

Useche, M. C. \& Castellano, A. (2002). Cambios implantados por el sector empresarial y su incidencia en el mercado de trabajo en América Latina. Revista Venezolana de Análisis de Coyuntura, 8(1), 53-63.

Valverde, M., Tregaskis, O., \& Brewster, C. (2000). Labor flexibility and firm performance. International Advances in Economic Research, 6, 649-661.

Virtanen, M., Kivimäki, M., Joensuu, M., Virtanen, P., Elovainio, M., \& Vahtera, J. (2005). Temporary employment and mental health: A review. International Journal of Epidemiology, 34, 610622.

Zelaschi, M. C. (2007, April). Invisibilidad de los riesgos laborales. La inestabilidad laboral y sus implicancias en la salud de los trabajadores. Presentation made at the $\mathrm{V}$ Congreso Latinoamericano de Sociología del Trabajo: Hacia una Nueva Civilización del Trabajo, Uruguay, Montevideo.

Zijl, M., van den Berg, G. J., \& Heyma, A. (2004). Stepping stones for the unemployed: The effect of temporary jobs on the duration until regular work (Discussion Paper $N^{\circ}$ 1241). Bonn: Institute for the Study of Labor.

Fecha de recepción: Mayo de 2009.

Fecha de aceptación: Enero de 2010. 